
Magdalena KOLENDA

\title{
CHANGES IN MILKING INTERVALS FOLLOWING AUTOMATIC MILKING SYSTEM INSTALLATION IN SELECTED DAIRY CATTLE HERDS IN POLAND
}

\section{ZMIANY CZASU MIĘDZY UDOJAMI PO ZAINSTALOWANIU AUTOMATYCZNEGO SYSTEMU DOJENIA W WYBRANYCH STADACH BYDŁA MLECZNEGO W POLSCE}

\author{
Department of Genetics and General Animal Breeding, University of Science and Technology, \\ Bydgoszcz, Poland \\ ${ }^{1}$ Lely East Ltd, Lisi Ogon, Poland \\ 2Department of Animal Genetics and Breeding, National Research Institute of Animal Production, \\ Balice near Kraków, Poland
}

\begin{abstract}
Streszczenie. W niewielu badaniach zajmowano się do tej pory długością czasu między kolejnymi udojami a jego wpływem na ilość mleka produkowaną przez krowy dojone przez automatyczny system dojenia. Celem niniejszych badań była analiza zmian czasu pomiędzy udojami w wybranych stadach bydła mlecznego w ciągu dwóch lat, jakie upłynęły od zainstalowania systemu. Materiał do badań uzyskano z trzech stad mlecznych bydła rasy polskiej bydło holsztyńsko-fryzyjskiej. Zebrano informacje dotyczące częstości udojenia, czasu pomiędzy dojami oraz ilości uzyskanego mleka. Baza danych, którą zastosowano do przeprowadzenia obliczeń statystycznych, zawierała ostatecznie 48,106 rekordów. Związek pomiędzy przynależnością do poszczególnych stad a czasem, jaki minął od instalacji robotów udojowych, sprawdzono za pomocą testu niezależności $\chi^{2}$. Zaobserwowano, że liczba udojów zmieniała się w czasie. Najmniej udojów zarejestrowano podczas początkowej fazy działania robota - zaraz po jego instalacji. W tym czasie zwierzęta przyzwyczajały się do urządzenia. Badanie wykazało, że niezależnie od stada i grupy krów (pierwiastek i wieloródek) największa liczba udojów przypadała między 6 do 9 godziną od ostatniego udoju (50\% krów było dojonych w tym przedziale czasowym). Najwyższa częstotliwość dojów (3.12-3.18) została zaobserwowana w stadzie, które charakteryzowało się najniższą średnią wydajnością mleka przypadającą na jedno dojenie.
\end{abstract}

Key words: automatic milking system, cattle, herd, milking frequency.

Słowa kluczowe: automatyczny system dojenia, bydło, stado, frekwencja udoju.

\section{INTRODUCTION}

Farmers by installing automatic milking systems (AMS) in their farms have gained an opportunity to track the parameters associated with milk performance. Detailed information about number of traits related to milk performance and their continuous monitoring allow to

Corresponding author - Adres do korspondencji: Beata Sitkowska, Department of Genetics and General Animal Breeding, University of Science and Technology, Mazowiecka 28, 85-084 Bydgoszcz, Poland, e-mail: beatas@utp.edu.pl 
analyse them in real time. AMS records parameters previously unavailable in traditional milking, such as: inter-milking interval, milking frequency, parameters directly related to both quarter milking and behaviour as well as feeding of animals. Unlike conventional milking systems (CMS), AMS involves free and voluntary movement of cows through the robot. Consequently, milkings are distributed unevenly throughout the day (Jacobs and Siegford 2012; Lyons et al. 2013; Piwczyński et al. 2013). Thus, the cows using AMS have different average milking intervals $(\mathrm{Ml}$ - the time interval between subsequent milking events, measured in hours from the previous milking event) and milking frequency (MF - the number of milkings per cow within 24 hours).

Researchers and farmers tend to associate the use of AMS with the significant increase in cow's milk yields (MY) which results from an increased MF. However, as evidenced by farming practice, the yield increase does not always occur, probably because MF is not always increased, or because MF is not the most important factor limiting milk production in cattle (Rotz et al. 2003; André et al. 2010; Laurs and Priekulis 2011; Lyons et al. 2013). The numbers for Ml change throughout the day in opposite direction than those for MF (Gygax et al. 2007). If average Ml for a cow is 6 hours, then average MF for that animal is 4 milkings per day. Farmers trying to increase MF in the herd while reducing MI. AMS profitability depends on the maximisation of milk yield within $24 \mathrm{~h} \mathrm{(kg} \mathrm{of} \mathrm{milk/24} \mathrm{h)} \mathrm{by} \mathrm{a} \mathrm{single} \mathrm{milking} \mathrm{robot.} \mathrm{This} \mathrm{objective}$ may be achieved by increasing the number of cows per robot (Castro et al. 2012; Rotz et al. 2003), increasing MF (Friggens and Rasmussen, 2001; Wagner-Storch and Palmer 2003; Pettersson et al. 2011; Carlström et al. 2013) or by both (André et al. 2010).

Until now, only a limited number of studies concerning the impact of MI or MF on MY in cows milked in AMS have been conducted (Hogeveen et al. 2001; Nixon et al. 2009; André et al. 2010; Lovendahl and Chagunda 2011; Pettersson et al. 2011). The purpose of this study is to analyse MI changes, connected with effective utilisation of AMS, in selected Polish dairy cattle herds over a period of 2 years following the system installation.

\section{MATERIAL AND METHODS}

The material used in the present study was collected from three Polish dairy farms with Polish Holstein-Friesian cattle. Similar housing and feeding conditions (PMR) were maintained at all facilities. In Farms A and B, robots were installed in October 2013, and in Farm C - in January 2013. The average number of cows in each farm was 60 . Herds were provided with different feed concentrates. Information on milking frequency, milking intervals, and milk yield was collected in respective herds throughout 2 years following the installation of robots. The share of primiparous cows in herds prior to the introduction of the AMS was approximately at a level of $50 \%$, and after robot's installation decreased to the average of $44-36 \%$. Changes in trait levels were analysed in 6-month periods starting from the moment of robot installation. Following processing and selection, the database contained a total of 48.160 records.

The database was used for statistical tests. The relationship between herd membership and the length of AMS operation was studied using the test of independence $\chi^{2}$ (SAS 2014). The $\chi^{2}$ test was also used for analysing the relationship between the milking intervals and the subsequent milking events. SAS statistical package and its FREQ procedure was used (SAS 2014). 


\section{RESULTS}

Prior to the introduction of the robot, during lactation cows from Farm B were milked for approximately 418 days, in Herds $A$ and $C$ for 395 and 349 days, respectively. Following AMS installation, the average number of milking days in Herd B increased to 460 days, in Herd $C$ to 357 days, and in Herd $A$ decreased to 348 days. Prior to installation, the milk yields in the selected herds were as follows: Herd $A-8.808 \mathrm{~kg}$ per lactation, Herd $B-10.831 \mathrm{~kg}$ and Herd C $-9.799 \mathrm{~kg}$.

The data was collected within two years that have been divided into four six-month periods. The initial 6-month period following AMS installation consisted of more than 9,000 complete milkings, which was the lowest number of milkings recorded during the present study. During the second (7-13 month) and fourth period following robot installation (19-24 month) the analysed number of milking events increased to over 15.000. The highest number of milkings (22.304 milkings) was recorded in the third 6-month period (13-18 month) - Table 1.

Table 1. Number of milkings per milking interval (MI) in different periods of study according to herd membership

Tabela 1. Liczba udojów w zależności od czasu między udojami (MI) w różnych okresach badań w poszczególnych stadach

\begin{tabular}{|c|c|c|c|c|c|}
\hline $\begin{array}{l}\text { Variable } \\
\text { Zmienne } \\
\text { Ml }\end{array}$ & $A$ & $\begin{array}{c}\text { Herd - Stado } \\
\text { B }\end{array}$ & $\mathrm{C}$ & Total - Łącznie & $\begin{array}{l}\chi^{2} \\
P\end{array}$ \\
\hline \multicolumn{6}{|c|}{ Period - Okres I } \\
\hline $\begin{array}{l}<6 \mathrm{~h} \\
6 \mathrm{~h}<9 \mathrm{~h} \\
9 \mathrm{~h}<12 \mathrm{~h} \\
12 \mathrm{~h}-14 \mathrm{~h}\end{array}$ & $\begin{array}{c}155(5.48) \\
1.520(53.69) \\
931(32.89) \\
225(7.95)\end{array}$ & $\begin{array}{l}510(10.43) \\
2.420(49.51) \\
1.417(28.99) \\
541(11.07)\end{array}$ & $\begin{array}{c}516(32.89) \\
706(45.00) \\
299(19.06) \\
48(3.06)\end{array}$ & $\begin{array}{r}1.181(12.72) \\
4.646(50.02) \\
2.647(28.50) \\
814(8.76)\end{array}$ & $\begin{array}{l}813.25 \\
\leq 0.0001\end{array}$ \\
\hline $\begin{array}{l}<6 \mathrm{~h} \\
6 \mathrm{~h}<9 \mathrm{~h} \\
9 \mathrm{~h}<12 \mathrm{~h} \\
12 \mathrm{~h}-14 \mathrm{~h}\end{array}$ & $\begin{array}{l}414(9.35) \\
2.267(51.20) \\
1.401(31.64) \\
346(7.81)\end{array}$ & $\begin{array}{r}\text { Perio } \\
1.144(14.73) \\
4.015(51.69) \\
1.855(23.88) \\
754(9.71)\end{array}$ & $\begin{array}{l}\text { Okres II } \\
589(20.69) \\
1.445(50.76) \\
680(23.88) \\
133(4.67)\end{array}$ & $\begin{array}{l}2.147(14.27) \\
7.727(51.37) \\
3.936(26.16) \\
1.233(8.20)\end{array}$ & $\begin{array}{l}296.24 \\
\leq 0.0001\end{array}$ \\
\hline \multicolumn{6}{|c|}{ Period - Okres III } \\
\hline $\begin{array}{l}<6 \mathrm{~h} \\
6 \mathrm{~h}<9 \mathrm{~h} \\
9 \mathrm{~h}<12 \mathrm{~h} \\
12 \mathrm{~h}-14 \mathrm{~h}\end{array}$ & $\begin{array}{l}479(5.69) \\
4.436(52.70) \\
2.855(33.92) \\
647(7.69)\end{array}$ & $\begin{array}{l}2.007(20.98) \\
4.725(49.40) \\
2.194(22.94) \\
639(6.68)\end{array}$ & $\begin{array}{c}754(17.45) \\
2.340(54.14) \\
1.043(24.13) \\
185(4.28)\end{array}$ & $\begin{array}{r}3.240(14.53) \\
11.501(51.56) \\
6.092(27.31) \\
1.471(6.60)\end{array}$ & $\begin{array}{l}1036.51 \\
\quad \leq 0.0001\end{array}$ \\
\hline \multicolumn{6}{|c|}{ Period - Okres IV } \\
\hline $\begin{array}{l}<6 \mathrm{~h} \\
6 \mathrm{~h}<9 \mathrm{~h} \\
9 \mathrm{~h}<12 \mathrm{~h} \\
12 \mathrm{~h}-14 \mathrm{~h}\end{array}$ & $\begin{array}{r}224(3.96) \\
2.644(46.70) \\
2.179(38.48) \\
615(10.86) \\
\end{array}$ & $\begin{array}{c}538(11.69) \\
2.328(50.60) \\
1.335(29.02) \\
400(8.69) \\
\end{array}$ & $\begin{array}{r}1.333(24.65) \\
2.740(50.68) \\
1.106(20.45) \\
228(4.22)\end{array}$ & $\begin{array}{l}2.095(13.37) \\
7.712(49.22) \\
4.620(29.48) \\
1.243(7.93) \\
\end{array}$ & $\begin{array}{l}1375.44 \\
\leq 0.0001\end{array}$ \\
\hline
\end{tabular}

Abbreviations used in Tables 1-2 and in Figures 1-3 - Skróty użyte w tab. 1-2 i na ryc. 1-3: periods (in months) after installation of AMS - okresy (w miesiącach) po instalacji AMS: I (1-6), II (7-12), III (13 -18), IV (19-24). 
The highest number of milking events was reported in Herd B and the lowest in Herd C. In all herds the lowest number of milkings was reported during the initial period following AMS introduction. (period I). Compared to the first period, the number of milkings occurring between 7 and 12 months after robot installation (period II) increased by $62 \%$. The highest number of milkings was reported 13-18 months after robot installation (period III). It was noted that in the last studied period, i.e. 19-24 months following the introduction of the AMS (period IV), the number of milkings decreased in Herd A and B, and slightly increased in Herd C (Table 1). By analyzing the number of milkings in different $\mathrm{Ml}$, it may be noted that the number of animals using the robot during the first six hours after the last visit varied according to herd and the studied period. During the first 6-month of AMS operation, the highest number of visits to AMS for all herds was reported 6 to 9 hours after the previous milking (over $50 \%$ of milkings occurred during that time) - Table 1, 2 .

Table 2. Number and percentage of milkings per milking intervals $(\mathrm{MI})$ reported for primiparous $(\mathrm{P})$ and multiparous (M) cows

Tabela 2. Liczba i procent udojów w zależności od czasu między udojami (MI) dla krów pierwiastek (P) i wieloródek (M)

\begin{tabular}{|c|c|c|c|c|c|c|c|c|}
\hline \multirow[b]{3}{*}{ MI } & \multicolumn{8}{|c|}{ Period - Okres } \\
\hline & \multicolumn{2}{|c|}{ I } & \multicolumn{2}{|c|}{ II } & \multicolumn{2}{|c|}{ III } & \multicolumn{2}{|c|}{ IV } \\
\hline & $P$ & M & $P$ & M & $P$ & M & $P$ & M \\
\hline$<6 \mathrm{~h}$ & $\begin{array}{l}635 \\
(963)\end{array}$ & $\begin{array}{l}546 \\
(20.27)\end{array}$ & $\begin{array}{r}1.318 \\
(1337)\end{array}$ & $\begin{array}{l}829 \\
(16.00)\end{array}$ & $\begin{array}{l}1.229 \\
(965)\end{array}$ & $\begin{array}{l}2.011 \\
(2101)\end{array}$ & $\begin{array}{l}867 \\
(10.39)\end{array}$ & $\begin{array}{r}1.228 \\
(16.76)\end{array}$ \\
\hline $6 \mathrm{~h}<9 \mathrm{~h}$ & $\begin{array}{r}3.456 \\
(52.40)\end{array}$ & $\begin{array}{r}1.190 \\
(44.19)\end{array}$ & $\begin{array}{r}5.323 \\
(53.98)\end{array}$ & $\begin{array}{r}2.404 \\
(46.39)\end{array}$ & $\begin{array}{r}7.076 \\
(55.57)\end{array}$ & $\begin{array}{l}4.425 \\
(46.24)\end{array}$ & $\begin{array}{r}4.336 \\
(51.98)\end{array}$ & $\begin{array}{c}3.376 \\
(46.07)\end{array}$ \\
\hline $9 \mathrm{~h}<12 \mathrm{~h}$ & $\begin{array}{r}1.920 \\
(29.11)\end{array}$ & $\begin{array}{l}727 \\
(27.00)\end{array}$ & $\begin{array}{r}2.460 \\
(24.95)\end{array}$ & $\begin{array}{r}1.476 \\
(28.48)\end{array}$ & $\begin{array}{r}3.603 \\
(28.29)\end{array}$ & $\begin{array}{l}2.489 \\
(26.01)\end{array}$ & $\begin{array}{r}2.525 \\
(30.27)\end{array}$ & $\begin{array}{r}2.095 \\
(28.59)\end{array}$ \\
\hline $12 \mathrm{~h}-14 \mathrm{~h}$ & $\begin{array}{l}584 \\
(8.86)\end{array}$ & 230 & $\begin{array}{l}760 \\
(7.71)\end{array}$ & $\begin{array}{l}473 \\
(9.13)\end{array}$ & $\begin{array}{l}826 \\
(6.49)\end{array}$ & $\begin{array}{l}645 \\
(6.74)\end{array}$ & $\begin{array}{l}614 \\
(7.36)\end{array}$ & $\begin{array}{l}629 \\
(8.58)\end{array}$ \\
\hline \multirow{2}{*}{$\begin{array}{l}\text { Total } \\
\chi^{2} \\
P\end{array}$} & 6.595 & 2.693 & 9.861 & 5.182 & 12.734 & 9.570 & 8.342 & 7.328 \\
\hline & \multicolumn{2}{|c|}{$\begin{array}{l}199.46 \\
\leq 0.0001\end{array}$} & \multicolumn{2}{|c|}{$\begin{array}{l}79.17 \\
\leq 0.0001\end{array}$} & \multicolumn{2}{|c|}{$\begin{array}{l}558.79 \\
\leq 00001\end{array}$} & \multicolumn{2}{|c|}{$\begin{array}{l}156.95 \\
\leq 0.0001\end{array}$} \\
\hline
\end{tabular}

The subsequent $\mathrm{Ml}$ (9-12 $\mathrm{h}$ since last visit) was also characterized by a great number of milkings (from $19.06 \%$ in Herd C to $32.89 \%$ in Herd A). Cows visited AMS less frequently during first six hours and 12-14 hours following the previous milking (periods I and II - first year after installation), although, the numbers varied depending on the herd (Table 1). In Herd B, the number of milkings during the first Ml was the lowest during the first six months $(10.43 \%$ of all milkings), during the second and third period (between 7th and 18ht month) the number increased (14.73\% and $20.98 \%$, respectively), and between 19th and 24th month of AMS operation the number of milkings decreased, however, it was still higher than at the beginning of the study. The opposite pattern was noted in Herd $\mathrm{C}$. The number of milkings occurring during the first $\mathrm{Ml}$ decreased throughout the studied period as it was the highest at the beginning of the study (32.89\%). In Herd A, during the first six months of study, the number of milkings occurring less than six hours after the previous milking, was reported to be at the level of $5.48 \%$. Within second $\mathrm{MI}$ this percentage increased to $9.35 \%$, then decreased to $5.69 \%$ in the third MI, and $3.96 \%$ in the last MI. During the final period of study (between 19th and 24th month), the number of cows that used AMS within 6 hours since last visit, was greater in Herd $C$ 
than in Herd A (24.65\% and $3.96 \%$ of animals, respectively). This pattern was reversed during the fourth MI, where the percentage of cows using AMS was greater for herd A than Herd C (10.86\%, and $4.22 \%$ respectively) - Table 1 .

It has been noted that, regardless of the studied period that elapsed since AMS installation, the highest number of milkings was mainly reported for primiparous cows (Table 2). For both groups of cows, primiparous and multiparous, the highest milking frequency was reported during the second MI, while the lowest was noted in the fourth MI.

In the initial period of AMS operation, MY reported for three herds varied from $8.8 \mathrm{~kg}$ (Herd A) to $9.87 \mathrm{~kg}$ (Herd C). In Herd $C$ the average milk yield decreased during first 18 months following robot installation and increased during the final period of study. The systematic improvement of milk yield was reported only for Herd A (the milk yield changed from $8.8 \mathrm{~kg}$ in the initial period to over $10 \mathrm{~kg}$ in the final one). The milk yield reported for Herd B increased only during first six months following AMS installation, in subsequent periods yield decreased (Fig. 1).

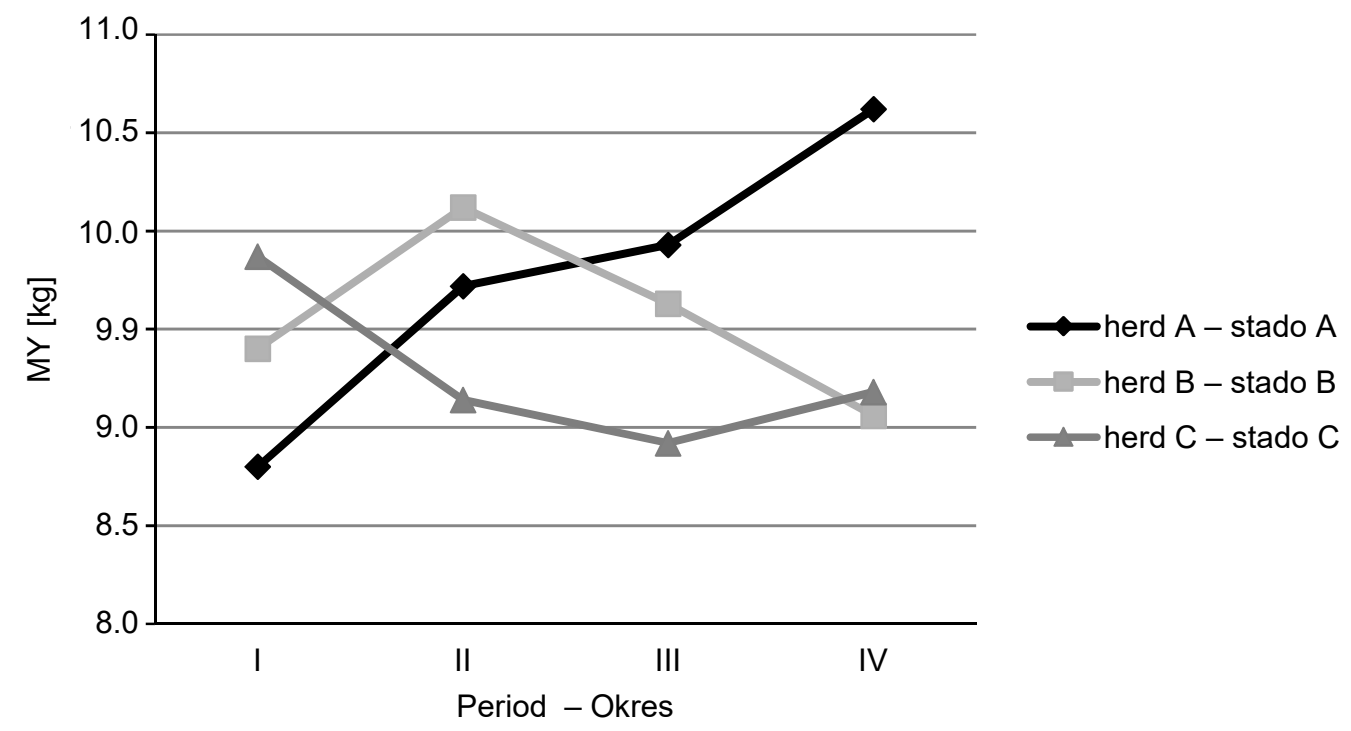

Fig. 1. Milk yield in different periods of study in herds $A, B$ and $C$

Ryc. 1. Wydajność mleka w różnych okresach badań w stadach $A, B$ i $C$

The average MF in the studied periods following AMS installation was 2.86. The highest milking frequencies for all periods of study were reported in Herd C. Although MF in Herd C decreased during the initial period of study, in later months the pattern was reversed and MF increased. MF for Herd B increased during first 18 months following robot installation and decreased during final six month of the study (between 19th and 24th month). Cows from Herd A were characterized by significantly lower milking frequency comparing to other studied herds, with the exception of the initial period following AMS operation (Fig. 2). The distribution of overall milking frequencies per milking intervals (MI) indicates that more than $50 \%$ of milkings occurred during the period between sixth and ninth hour since the previous milking event. On the average, $27.76 \%$ of milkings occurred during the third MI (9-12 h since the previous milking). The share of milkings taking place before 6 hours and after 12 hours since the previous milking event was significantly smaller (Fig. 3). 


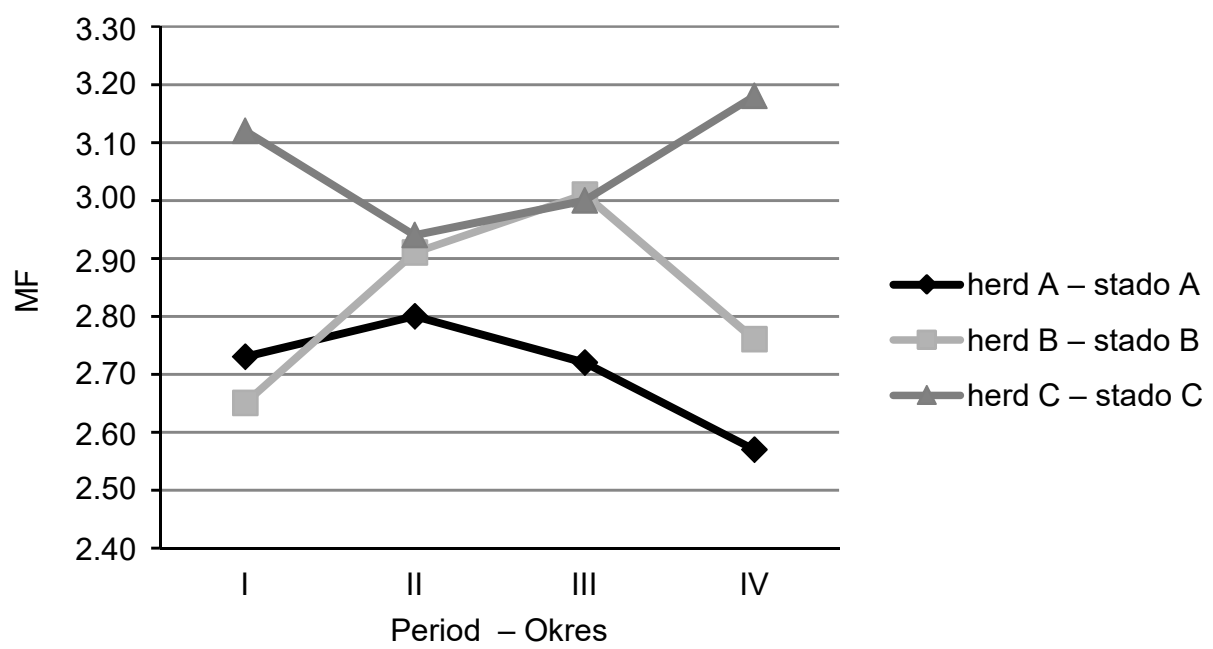

Fig. 2. Milking frequency (MF) in different periods of study in herds $A, B$ and $C$ Ryc. 2. Frekwencja udojów (MF) w różnych okresach badań w stadach $A, B$ i $C$

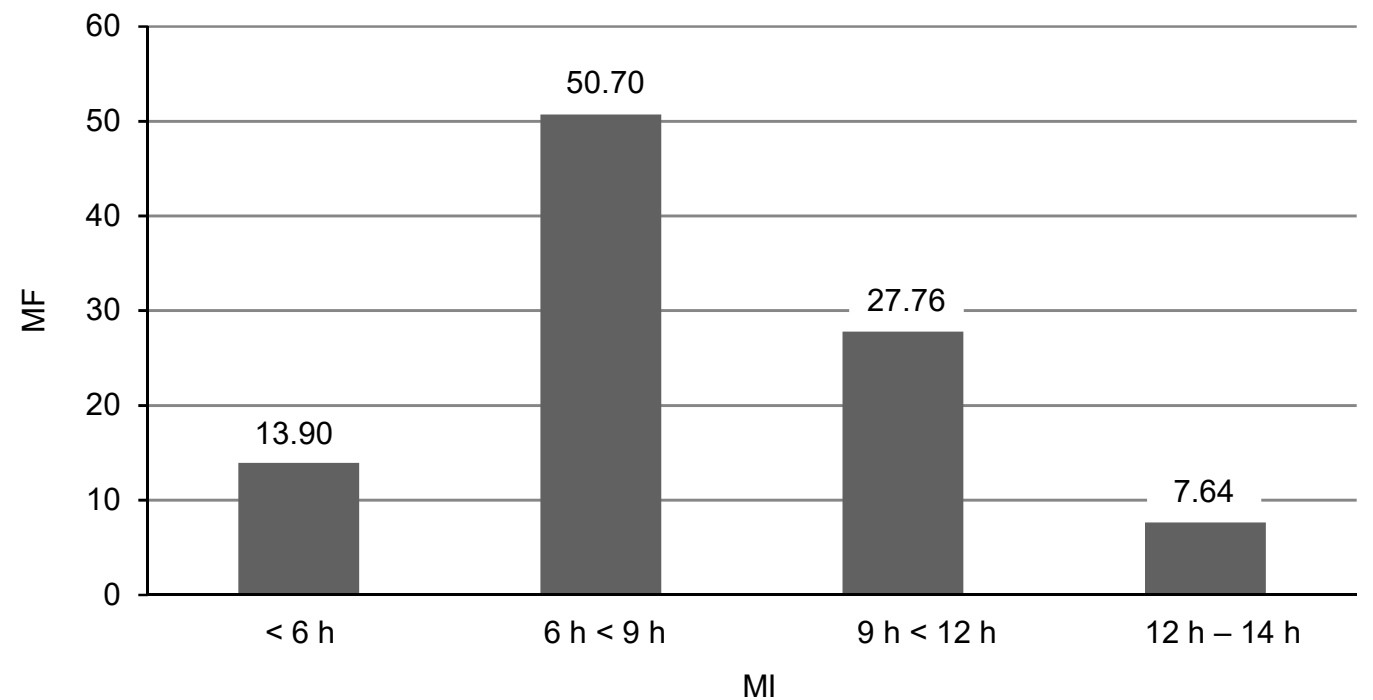

Fig. 3. Milking frequency (MF) per milking interval (MI)

Ryc. 3. Frekwencja udojów (MF) w zależności od czasu między udojami (MI)

\section{DISCUSSION}

The results of the present study indicate that the milking yield (MY) obtained for three different cattle herds varied depending on time that elapsed since the installation of AMS. MY varied from $8.8 \mathrm{~kg}$ in the initial period of robot operation to $10 \mathrm{~kg}$ in the final period. Those figures are lower than those reported by Hogeveen et al. (2001), Løvendahl and Chagunda (2011) as well as Castro et al. (2012). They found that the average milk yield in barns equipped with AMS varied from $10.70 \mathrm{~kg}$ to $11.8 \mathrm{~kg}$. Moreover, the results suggest that the introduction of AMS improved MY in Herds A, which is in accordance with the results presented by Speroni et al. (2006), who reported that cows milked in the AMS yielded more milk than those milked in traditional systems. 
Lyons et al. (2013) have reported that the highest proportion of milkings occurred within the period between 9th and 11th hour since the last milking event. In this study, approximately $50 \%$ of cows were milked 6-9 hours after the previous milking event. This is consistent with the result of the present studies, where more than $50 \%$ of milkings occurred during the period between sixth and ninth hour. Gygax et al. (2007) found that almost $20 \%$ of all milkings occurred 12 hours after the last milking event. The same authors observed that $13.5 \%$ of milkings occurred during first interval ( $<6$ hours since last visit to AMS) and $65.5 \%$ between sixth and 12th hour.

Moreover, Friggens and Rasmussen (2001) found that, with AMS, MY per milking is closely associated with MI. Sorensen et al. (2008) and Pettersson et al. (2011) also observed that increased MF resulted it an increased MY. Cows with a higher MF were observed to produce $20 \%$ more milk than cows with the lowest MF (Løvendahl and Chagunda 2011). In research of Speroni et al. (2006), Ml was lower for primiparous cows (8 h $46 \mathrm{~min} \pm 9 \mathrm{~min}$ ) than for multiparous (9 h $43 \mathrm{~min} \pm 15 \mathrm{~min}$ ).

In the present study the average MF was 2.86 , which is in accordance with results reported by Deming et al. (2013), who noted that cows were milked $2.8 \pm 0.4$ times a day. Gygax et al. (2007) reported that in farms with Lely Astronaut AMS the average daily MF was at the level of 2.5 (range: 0.8 to 3.9 milkings per cow), while Munksgaard et al. (2011) found that all cows were milked 2-4.2 times a day. In the research of Laurs and Priekulis (2011) only $13-21 \%$ of animals were milked four times a day, $31-52 \%$ of cows visited the robot three times a day, and $33-48 \%$ twice a day. Similar results were reported by Castro et al. (2012), who noted that, on average, cows were milked $2.69 \pm 0.3$ times a day. Madsen et al. (2010) reported the average of 3 milking events per day, which is similar to the results obtained in the present study for the Herd C. In turn, an increased number of milking events per day, i.e. from 2.2 to 2.5, was observed by Wagner-Storch and Palmer (2003), Gygax et al. (2007) and Bach et al. (2009). Moreover, Castro et al. (2012) suggested that the optimum frequency of milking sessions per day is between 2.4 and 2.6 - numbers that were lower than those reported in the present study.

According to Hogeveen et al. (2001), the average Ml was 9.2 hours, and MF was 2.6 milkings per day. Mačuhová et al. (2003) noted that the interval between milkings was $11.3 \pm 0.5$ hours, which resulted in 2,1 milking per day. Madsen et al. (2010) reported MF to be 2.96 milkings per day. Speroni et al. (2006), reported that MF varied according to the season of the year, with higher frequency during autumn-winter season (2.7). They also observed that MF was higher for the group of primiparous cows (2.8) than multiparous (2.5). Deming et al. (2013) suggested that increased MF resulted in higher MY. This may be related to a reduced number of animals per robot which in turn makes it easier for animals to access feed and water.

In the situation when AMS is not being used for at least $10 \%$ of a day, cows that are lower in herd's rank have an easier access to the robot. In order to encourage cows to visit AMS more frequently various concentrates may be used (Bach et al. 2007; Madsen et al. 2010). Such measures gain particular significance directly after AMS introduction.

André et al. (2010) emphasized that, in farms equipped with AMS, an increase in MF and in herd size may bring benefits, but the success of this strategy is related primarily to animals' MY. As underscored by Nixon et al. (2009), following AMS introduction the MI may vary widely from animal to animal and may be very long or very short. However, it will not be shorter than 4 hours, as cows need this time for recovery. 


\section{CONCLUSIONS}

It has been shown that AMS has the potential to improve labour and lifestyle on dairy farms, it may also induce some significant efficiency gains. Since the system relies on cows' willingness to use AMS, it is important to understand how the installation of the robots influences the animals. Investigating changes that occurred after the introduction of the robots may bring many benefits to farmers as it may indicate the necessary changes that could improve milk production.

Based on the results obtained in this study, it was noted that the number of milkings per days changed according to the period of time that elapsed since AMS installation. The lowest number of milkings meeting the analysis criteria was reported in this study during the initial period following AMS installation, which might have been caused by the fact that the animals had to adapt to AMS. It was also reported that, regardless of herd and lactation group (the distinction between primiparous or multiparous cows) the highest number of voluntary visits in milking robot occurred between the sixth and ninth hour since previous visit, with $50 \%$ of cows using the robots during that interval. In all studied periods, the highest milking frequency (3.12-3.18) was reported in herd with the lowest average milk yield per milking. At the same time, milking frequency was found to be lower (2.72-2.57) in the herd in which average milk yield was growing systematically. The group of primiparous cows was found to use AMS more frequently than the animals in subsequent lactations, which is related to the AMS access settings, allowing the group of primiparous cows to use the robot with a greater frequency.

\section{REFERENCES}

André G., Berentsen P.B.M., Engel B., Koning C.J.A.M. de, Oude-Lansink A.G.J.M. 2010. Increasing the revenues from automatic milking by using individual variation in milking characteristics. J. Dairy Sci. 93, 942-953.

Bach A., Iglesias C., Calsamiglia S., Devant M. 2007. Effect of amount of concentrate offered in automatic milking systems on milking frequency, feeding behavior, and milk production of dairy cattle consuming high amounts of corn silage. J. Dairy Sci. 90, 5049-5055.

Bach A., Devant M., Igleasias C., Ferrer A. 2009. Forced traffic in automatic milking systems effectively reduces the need to get cows, but alters eating behavior and does not improve milk yield of dairy cattle. J. Dairy Sci. 92, 1272-1280.

Carlström J., Pettersson C., Johansson G., Strandberg K., Stålhammar E., Philipsson H. 2012. Feasibility of using automatic milking system data from commercial herds for genetic analysis of milkability. J. Dairy Sci. 96, 5324-5332.

Castro A., Pereira J.M., Amiama C., Bueno J. 2012. Estimating efficiency in automatic milking systems. J. Dairy Sci. 95, 929-936.

Deming J.A., Bergeron R., Leslie K.E., DeVries T.J. 2013. Associations of housing, management, milking activity, and standing and lying behavior of dairy cows milked in automatic systems. J. Dairy Sci. 96, 344-351.

Friggens N.C., Rasmussen M.D. 2001. Milk quality assessment in automatic milking system: accounting for the effects of variable intervals between milking on milk composition. Livest. Prod. Sci. 73, 45-54.

Gygax L., Neuffer I., Kaufmann C., Hauser R., Wechsler B. 2007. Comparison of functional aspects in two automatic milking systems and auto-tandem milking parlors. J. Dairy Sci. 90, 4265-4274. 
Hogeveen H., Ouweltjes W., Koning C.J.A.M. de, Stelwagen K. 2001. Milking interval, milk production and milk flow-rate in an automatic milking system. Livest. Prod. Sci. 72, 157-167.

Jacobs J.A., Siegford J.M. 2012. Invited review: The impact of automatic milking systems on dairy cow management, behavior, health, and welfare. J. Dairy Sci. 95, 2227-2247.

Laurs A., Priekulis J. 2011. Variability of milking frequency and intervals between milkings in milking robots. Agron. Res. Biosys., Eng. Spec. Iss. 1,135-141.

Lyons N.A., Kerrisk K.L., Dhand N.K. 2013. Factors associated with extended milking intervals in a pasture-based automatic milking system. Livest. Sci. 158, 179-188.

Løvendahl P., Chagunda M.G. 2011. Covariance among milking frequency, milk yield, and milk composition from automatically milked cows. J. Dairy Sci. 94, 5381-5392.

Mačuhová J., Tančin V., Bruckmaier R.M. 2003. Oxytocin release, milk ejection and milk removal in a multi-box automatic milking system. Livest. Prod. Sci. 81, 139-147.

Madsen J., Weisbjerg M.R., Hvelplund T. 2010. Concentrate composition for Automatic Milking Systems - Effect on milking frequency. Livest. Sci. 127, 45-50.

Munksgaard L., Rushen J., Passillé A.M. de, Krohn C.C. 2011. Forced versus free traffic in an automated milking system. Livest. Sci. 138, 244-250.

Nixon M., Bohmanova J., Jamrozik J., Schaeffer L.R., Hand K., Miglior F. 2009.Genetic parameters of milking frequency and milk production traits in Canadian Holsteins milked by an automated milking system. J. Dairy Sci. 3422-3430.

Pettersson G., Svennersten-Sjaunja K., Knight C.H. 2011. Relationships between milking frequency, lactation persistency and milk yield in Swedish Red heifers and cows milked in a voluntary attendance automatic milking system. J. Dairy Res. 78, 379-384.

Piwczyński D., Sitkowska B., Aerts J., Kolenda M. 2013.The daily distribution of milkings of cows in farms equipped with the automatic milking system. Acta Sci. Pol. Zootech.12, 61-70.

Rotz C.A., Coiner C.U., Soder K.J. 2003.Automatic milking systems, farm size, and milk production. J. Dairy Sci. 86, 4167-4177.

SAS Institute Inc. 2014. SAS/STAT® 9.4 User's Guide Cary, NC: SAS Institute Inc.

Sorensen A., Muir D.D., Knight C.H. 2008. Extended lactation in dairy cows: effects of milking frequency, calving season and nutrition on lactation persistency and milk quality. J. Dairy Res. 75, 90-97.

Speroni M., Pirlo G., Lolli S. 2006. Effect of automatic milking systems on milk yield in a hot environment. J. Dairy Sci. 89, 4687-4693.

Wagner-Storch A.M., Palmer R.W. 2003. Feeding behavior, milking behavior, and milk yields of cows milked in a parlor versus an automatic milking system. J. Dairy Sci. 86, 1494-1502.

Abstract. Only a limited number of studies looking into the impact of milking intervals on milk yield in cows milked in automatic milking system (AMS) have been conducted. The purpose of this study was to analyse changes in milking intervals in selected dairy cattle herds over a period of 2 years following AMS installation. The material for the present study was collected in Poland from three dairy farms with Polish Holstein-Friesian cattle. Information concerning milking frequency, milking intervals, and milk yield was collected. The database on which statistical tests were performed 48.160 records. The relationship between herd membership and the time that elapsed since the installation of the robot was investigated using the chi-square test of independence. It was found that over the studied period of time the number of milkings per day changed. The lowest number of milkings was recorded in the initial period following AMS installation, when animals were still adapting to AMS. This study established that, regardless of herd and group of cows (primiparous or multiparous) the largest number of voluntary visits to the milking robot occurred 6-9 hours after the last visit, with $50 \%$ of cows using the robots during that interval. In all periods under study, the highest milking frequency (3.12-3.18) was reported in the herd with the smallest average milk yield per milking. 
